\title{
PANAEOLUS SUBFIRMUS (AGARICALES, BASIDIOMYCOTA), A SPECIES NEW FOR POLAND
}

\author{
MareK Halama
}

Since its publication, the author of Halama (2014) has brought to our attention corrections that need to be made to the Acknowledgements.

ACKNOwLEDGEMENTS. I am grateful to Bernadeta Pawlik for her kind help in completing the mycological literature, to Maciej Romański for his invaluable assistance during field trips, and to the anonymous reviewers for helpful suggestions on the manuscript. The research was supported by the Wroclaw Research Centre EIT+ under the project 'Biotechnologies and advanced medical technologies' - BioMed (POIG.01.01.02-02-003/08), financed from the European Regional Development Fund (Operational Programme Innovative Economy, 1.1.2).

\section{REFERENCES}

Halama M. 2014. Panaeolus subfirmus (Agaricales, Basidiomycota), a species new for Poland. Polish Bot. J. 59(2): 271-277. DOI: $10.2478 / \mathrm{pbj}-2014-0029$.

We apologize to our readers for any inconvenience this has caused. 